\title{
The Effect of Flood on the Water Quality and the Epilithic Diatom Assemblage in the River Affected by Heavy Metals Produced by Closed Copper Mines
}

\author{
MICHIAKI SUMITA 1 , TAKAHARU HONJO ${ }^{2}$, TOSHIHARU WATANABE ${ }^{3}$, \\ YOSHIYUKI NAKANISHI ${ }^{2}$, and TOSHIHIRO MINAMI ${ }^{4}$
}

\author{
${ }^{1}$ Kamimotoori-machi 86, Komatsu City, Ishikawa 923-0955, JAPAN \\ ${ }^{2}$ Faculty of Science, Kanazawa University/Kakuma-machi, Kanazawa City, Ishikawa 920-1192, JAPAN \\ ${ }^{3}$ Higashigawa-cho 518, Shinkyogoku st., Nakagyo-ku, Kyoto City, 604-8046, JAPAN \\ ${ }^{4}$ Faculty of Business Administration and Information Science, Kanazawa Gakuen University \\ /Sue-machi 10, Ishikawa 920-1164, JAPAN
}

\begin{abstract}
The River Godani, a tributary of the River Kakehashi which joins with main stream of the River Kakehashi about $5 \mathrm{~km}$ downstream, is known for its pollution due to the mining water. Typhoon No.7 passed through Ishikawa Prefecture on September 22 in 1998 with locallized torrential down pour.

In this study, We examined the effect of the Typhoon No.7 on those Rivers from the viewpoint environmental factors of the river water and the ecological viewpoint based on the change of the epilithic diatom assemblages on the river bed.

Each of the four surveys $\langle 1998$ - 1999〉 showed a tendency, in its measurement of EC values decreasing from upperstream to downstream in order.

The concentration of heavy metals increased in all sites after 6 months. At each sampling site 6 months after flood, the concentration of $\mathrm{Cu}$ was 1.3-2.0 higher, and that of $\mathrm{Zn}$ was 1.3-3.3 times greater than those obtained before flood, while the concentration of $\mathrm{Cd}$ showed no district difference from those obtained before flood.

The concentration of heavy metals in attached materials was far higher than that of heavy metals in the mud of river bed. This may be due to the fact that the greatest part of attached material consist of epilithic algae (organic material) and the rest is silt (inorganic material), while in the case of mud the volume of silt is much greater, than that of residue of epilithic algae. After all weight of epilithic algae per unit volume is small compared with silt, but they absorbs heavy metals. On the other hand, inorganic silt only absorbs heavy metals but no process of concentration occurs.

Three surveys, B (November 2, 1988), C (December 21, 1988) and D (March 24, 1999) were after flood.

In the survey B, Achnanthes minutissima which has strong tolerance to heavy metals was the most abundant taxon in almost all sampling sites.

It is noticeable that in all sites of $D$ (150 days after flood), the most abundant taxon was $A$. minutissima. The temporary change of the most abundant taxon at Sites 3,4 (cf. Fig. 2) is considered to be due to the fact that materials on the river bed easily came off and were carried downstream and pilled up there temporarily.
\end{abstract}

Key words : epilithic diatom, the most abundant taxon, electric conductivity, flood, heavy metals 


\section{INTRODUCTION}

Typhoon No.7 through Ishikawa Prefecture on September 22, 1998 with localized torrential down pour. The flood gave the greatest damage to the two basins of the River Kakehashi and its tributary, the River Godani since the flood in 1896.

The River Godani, a tributary of the River Kakehashi about $5 \mathrm{~km}$ downstream is known for its pollution due to the mining waste.

Before and after the closing of Ogoya copper mines, many studies were made on the recovery of organisms due to the decrease of the inflow of heavy metals $(\mathrm{Cu}, \mathrm{Zn}$ and $\mathrm{Cd})$, using biological indicators ${ }^{1-5}$.

Ito (1975) considered the pollution of Godani and Kakehashi basins as an inorganic pollution due to the still remaining mine-effluent of the closed Ogoya mines, and proved it using aquatic insects and epilithic algae as biological indicators ${ }^{6}$.

In this study we also make use of these biological indicators. We made, however special effort trying to find out the sequence of change of the content of heavy metals before and after the greatest increase and decrease of river water caused by the Typhoon No.7(Sep., 1998).

Our research covered the 150 days from Sept., to March 1999 through 4 periods (A: Before flood, B: 40 days after flood, C: 80 days after flood, D: 150 days after flood) following the sequence of changes of the composition of epilithic diatoms.

\section{MATERIALS AND METHODS}

As shown Fig.1 samples were collected from 4 sampling sites shown in Fig. 1. Sites 1 and 2 in the River Godani were Kurataniguchi and Sawa. Sites 3 and 4 in the River Kakehashi were Hanazaka Shorenji.

In Site 1, percolate water from abandoned Kuratani mine and flowing water from the setting basin, flow together to the River Omodani, which joins the River Godani. Upperstream district of Sites 3 and 4 had several abandoned mines, but their polluting influence on the River Kakehashi was very little.

The material were collected in four different times, namely before flood(A) and temporary repairs of road and river walls after the flood caused by Typhoon No.7(B-D). $B$ was done about 40 days after the flood on November 2, 1998. $\mathrm{C}$ was about 80 days the flood December 21, 1998. D was carried out 150 days after the flood March 24, 1999.

\section{Environmental factors}

The water samples were taken from the surface water in each site. The determination of water temperature, $\mathrm{pH}$ and EC(electric conductivity) was conducted on the spot. A pH meter(model B-212, HORIBA, Japan) and an electric conductivity meter(model B-173, HORIBA, Japan) were used.

1) Determination of heavy metals $(\mathrm{Cu}, \mathrm{Zn}$ and $\mathrm{Cd})$ in river waters

The water samples were taken from the depth of 20-30 cm from river surface and were filtered through a $0.45 \mu \mathrm{m}$ membrane

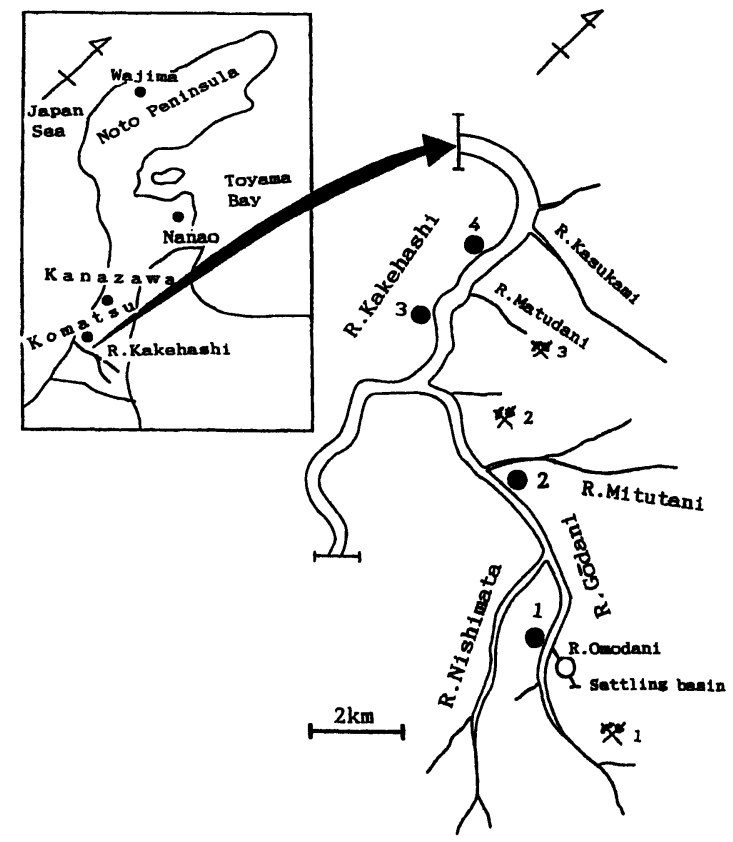

Fig. 1 Sampling sites

1 : Kurataniguchi

2 : Sawa

3 : Hanasaka

4 : Shorenji

x 1 : Kuratani (ogoya) former mining area

× 2 : Kanahira former mining area

x 3 : Gokouji former mining area 
filter(Millipore Corps, Type HA) with an aspiration pump soon after the sampling, as the treatment of $\mathrm{spa}^{7}$. $1 \mathrm{~m} l$ of concentration nitric acid was added to $100 \mathrm{ml}$ of the filtrate. The water samples were stored in the glass bottles.

On the basis of calibration curve established by series of the standard solutions, the concentration of metals $(\mathrm{Cu}, \mathrm{Zn}$ and $\mathrm{Cd}$ ) was determined by FAAS(flame atomic absorption spectometer) for $\mathrm{Cu}$ and $\mathrm{Zn}$ or GFAAS(graphite furnace atomic absorption spectometer) for $\mathrm{Cd}$.

All the working solution of metals were prepared to be $0.1 \mathrm{M} \mathrm{HNO}_{3}$ solution. In the case of determination of $\mathrm{Ca}$, a $1000 \mathrm{mg} / \mathrm{l}$ was added to the standard and the sample solution an interference suppressant. The determination was replicated at least three times, and the abnormal data were eliminated by using the Grubb's test.

2) Determination of heavy metals $(\mathrm{Cu}, \mathrm{Zn}$ and $\mathrm{Cd})$ in attached materials

Sampling of attached materials was carried out with the same criteria as in the case of mud on the river. The attached materials consisted of algae and silt(clayey particles of nearly $10 \mu \mathrm{m}$ in diameters).

At the river bed in the depth of $30-40 \mathrm{~cm}$, the stones with almost parallel surface to that of water were selected. The attached materials on the upper surface were brushed down by using a nylon brush and were fixed in a formaldehyde solution.

The samples were centrifuged $(2000 \mathrm{rpm} \times$ $10 \mathrm{~min}$.) in order to remove bulk waters. The supernatant materials were discarded and the precipitate was dried over-night at $80^{\circ} \mathrm{C}$. Each of the dried samples(10-20 mg) was transferred into a glass test tube. A small amount of water was added so as to wet the sample and $1 \mathrm{~m} l$ of concentrated nitric acid water was then added. The tube was set in the quick digesters, and was treated at half power mode, i.e. $350 \mathrm{~W}$ for $30 \mathrm{~min}$. Then $1 \mathrm{ml}$ of the mixture of concentrated nitric acid and perchlonic acid $(3: 1 \mathrm{v} / \mathrm{v})$ was added to the sample ${ }^{8)}$.

It was treated in the digester at $350 \mathrm{~W}$ for $30 \mathrm{~min}$ and continually at $700 \mathrm{~W}$ for $20 \mathrm{~min}$ again. Most of the sample was dried up under this condition, but the heating treatment of
$700 \mathrm{~W}$ was continued until all the content was dried up. After cooling the tube, $1 \mathrm{ml}$ of $1 \mathrm{M}$ nitric acid was added to residue in the tube to leach out metals by ultrasonic treatment. In order to remove the white crystals of silicate the suspension was filtered through a 0.45 $\mu \mathrm{m}$ membrane filter. The filtrate was transferred to a $25 \mathrm{ml}$ or $50 \mathrm{ml}$, volumetric flask. A proper amount of nitric acid was added so that final solution showed be $0.1 \mathrm{M}$ nitric acid solution, and another $1000 \mathrm{mg} / \mathrm{l}$ of nitric acid was added as an interference suppressed. Then, the solution was diluted up to the line with the distilled deionized water.

The determination was replicated at least three times, and the abnormal data were rejected by using the Grubb's test.

3) Determination of heavy metals $(\mathrm{Cu}, \mathrm{Zn}$ and $\mathrm{Cd})$ in the mud of river bed

The sediment on the river bed mud was taken, and the relatively large stones and psephites in it were removed. Then, the residual mud in the river waters was transferred to a polyethylene bottle and was brought back to the laboratory. The samples were stored in a refrigerator prior to analysis. Each of the samples was transferred to 500 $\mathrm{m} l$ beaker. Water was added to it and was mixed with a glass rod. After leaving it for 3 min, psephites and fine sands were precipitated down quickly, while the floating particles were suspended in the mixture. The suspension was taken out by centrifugation $(2000 \mathrm{rpm} \times 10 \mathrm{~min})$ and was over-night at $110^{\circ} \mathrm{C}$.

Each of the dried samples was digested in the case of attached materials, and the concentration of metals was determined by FAAS(Cu, Zn) or GFAAS(Pb, Cd).

\section{Sampling and treatment of attached algae}

In the sampling of attached algae, the following criteria were used ${ }^{9)}$ :

a) Samples were taken in riffles about 30 $\mathrm{cm}$ deep and with about $40 \mathrm{~cm} / \mathrm{s}$ flow rate.

b) Samples were collected only from the flat stone surfaces parallel to the water surface.

c) In places where river water did not flow, samples were taken from a 
vertical surfaces of any non-living substrate $30 \mathrm{~cm}$ deep in water to avoid the effect of sedimentary matters.

d) To obtain assemblages which had reached maturity in their successional process, only those with large standing crops were collected.

These samples were cleaned with sulfuric acid and potassium permanganate and mounted in cedax.

Diatom taxa were identified using micrographs at 1500 magnification referring to the following descriptions ${ }^{10-15)}$.

The relative abundance of diatom taxa in each assemblage was obtained by counting the number of individuals.

\section{RESULTS AND DISCUSSION}

\section{Environmental factors}

1) Water temperature, $\mathrm{pH}$ and $\mathrm{EC}$

As shown in Table 1 , the range of water temperature was from $6.9^{\circ} \mathrm{C}(\mathrm{C}$, Site 2) to 20.9 ${ }^{\circ} \mathrm{C}$ (A, Site 4).

The river water of the Omodani, which joins the River Godani at Kurataniguchi(Site 1 ), is polluted by the percolated water from the now abandoned Kuratani mines and showed $\mathrm{pH}$ values 4.6-5.4 when measured.

In order to neutralize the condition, treatment by $\mathrm{Ca}(\mathrm{OH})_{2}$ was useful way.

Changing heavy metals $(\mathrm{Cu}, \mathrm{Zn}$ and $\mathrm{Cd})$ to their hydroxide and letting them precipitated to the bottom of water body. So the range of $\mathrm{pH}$ values measured in this survey was 6.8 (D, Site 1) to 8.7(D, Site 3).

EC values were ranged from $98 \mu \mathrm{s} / \mathrm{cm}(\mathrm{C}$, Site 3) to $320 \mu \mathrm{s} / \mathrm{cm}(\mathrm{D}$, Site 1$)$. In each sampling time, similar tendency of measurement values was observed reduction of values from Site 1 to Site 2 in order.

The concentration of heavy metals in the river water was high at Site 1 near the precipitation tank, but the concentration of heavy metals in the river water naturally lower where there is no more river water bringing heavy metals into the middle and lower stream. This tendency remains the same after the flood.

2) Concentration of heavy metals $(\mathrm{Cu}, \mathrm{Zn}$ and $\mathrm{Cd})$ in the river waters

As shown in Table 2, the analytical results
Table 1 Water temperature, $\mathrm{pH}$ and EC

\begin{tabular}{c|c|c|c|c|c}
\hline Factor & $\begin{array}{c}\text { Sampling } \\
\text { Site }\end{array}$ & $\mathrm{A}$ & $\mathrm{B}$ & $\mathrm{C}$ & $\mathrm{D}$ \\
\hline Water & 1 & 19.0 & 14.7 & 7.2 & 10.3 \\
Temper- & 2 & 20.0 & 14.4 & 6.9 & 10.0 \\
ature & 3 & 20.5 & 13.8 & 7.2 & 8.3 \\
(C) & 4 & 20.9 & 14.7 & 7.7 & 8.6 \\
\hline & 1 & 6.9 & 7.1 & 7.2 & 6.8 \\
& 2 & 7.3 & 7.9 & 8.1 & 7.4 \\
$\mathrm{pH}$ & 3 & 7.9 & 7.8 & 8.0 & 8.7 \\
& 4 & 8.0 & 7.8 & 7.8 & 7.6 \\
\hline & 1 & 242 & 280 & 178 & 320 \\
$\mathrm{EC}$ & 2 & 171 & 190 & 110 & 170 \\
$(\mu \mathrm{s} /$ & 3 & 120 & 135 & 98 & 100 \\
$\mathrm{~cm})$ & 4 & 130 & 134 & 110 & 100 \\
\hline
\end{tabular}

A : Before flood, September 4, 1998

B : About 40 days after flood, November 2, 1998

C : About 80 days after flood, December 21, 1998

D : About 150 days after flood, March 24, 1999

Table 2 Concentration of heavy metals( $\mathrm{Cu}, \mathrm{Zn}$ and Cd) in the river water

\begin{tabular}{c|c|c|c|c|c}
\hline Factor & $\begin{array}{c}\text { Sampling } \\
\text { Site }\end{array}$ & $\mathrm{A}$ & $\mathrm{B}$ & $\mathrm{C}$ & $\mathrm{D}$ \\
\hline & 1 & 0.15 & 0.24 & 0.22 & 0.25 \\
$\mathrm{Cu}$ & 2 & 0.027 & 0.035 & 0.054 & 0.053 \\
$(\mathrm{mg} / l)$ & 3 & 0.015 & 0.015 & 0.019 & 0.019 \\
& 4 & 0.013 & 0.014 & 0.020 & 0.020 \\
\hline & 1 & 0.92 & 1.26 & 1.39 & 2.70 \\
$\mathrm{Zn}$ & 2 & 0.38 & 0.37 & 0.41 & 0.74 \\
$(\mathrm{mg} / l)$ & 3 & 0.19 & 0.27 & 0.20 & 0.25 \\
& 4 & 0.08 & 0.22 & 0.19 & 0.26 \\
\hline & 1 & 0.0043 & 0.0061 & 0.0051 & 0.0074 \\
$\mathrm{Cd}$ & 2 & 0.0012 & 0.0022 & 0.0016 & 0.0021 \\
$(\mathrm{mg} / l)$ & 3 & 0.0006 & 0.0015 & 0.0009 & 0.0008 \\
& 4 & 0.0006 & 0.0013 & 0.0008 & 0.0008 \\
\hline
\end{tabular}

of the concentration of heavy metals in the river water were as follows; $\mathrm{Cu}$ from 0.013 $\mathrm{mg} / \mathrm{l}$ (A, Site 4) to $0.25 \mathrm{mg} / \mathrm{l}(\mathrm{D}$, Site 1$) ; \mathrm{Zn}$ from $0.08 \mathrm{mg} / l$ (A, Site 4) to $2.7 \mathrm{mg} / l$ (D) Site 1); Cd from $0.0006 \mathrm{mg} / \mathrm{l}$ (A, Sites 3,4$)$ to $0.0074 \mathrm{mg} / l$ (D, Site 1).

Each survey showed a similar tendency in the measurement of their concentration to decrease from upperstream to downstream, as in the case of EC values.

3) Concentration of heavy metals in attached materials on the river stones

As shown in Table 3, the analytical result of heavy metals in attached material on the river bed, stones were as follows; $\mathrm{Cu}$ was from $1500 \mu \mathrm{g} / \mathrm{g}$ (A, Site 4) to $82300 \mu \mathrm{g} / \mathrm{g}$ (D, Site 3); Zn from $2100 \mu \mathrm{g} / \mathrm{g}$ (C, Site 4) to 40600 
$\mu \mathrm{g} / \mathrm{g}$ (D, Site 3); Cd from $3.8 \mu \mathrm{g} / \mathrm{g}$ (B, Site 1) to $30 \mu \mathrm{g} / \mathrm{g}$ (A, Site 3 ).

The values of concentration of $\mathrm{Cu}$ decreased both before flood(A) and $\operatorname{after}(\mathrm{B}, \mathrm{C})$ from upstream to downstream, but the measurement after. flood(D) showed increase in Sites 3 and 4 in the downstream area. These values were even 50.7-51.4 times more than those obtained in the same sites before flood(A). The values of $\mathrm{Zn}$, showing the same tendency, were 6.1-8.1 times more than those obtained before the fled.

The values of $\mathrm{Cd}$ unlike those of $\mathrm{Cu}$ and $\mathrm{Zn}$ showed no disrinct change either in different sites or in different periods.

4) Concentration of heavy metals in the mud of river bed

As shown in Table 4, the analytical results

Table 3 Concentration of heavy metals $(\mathrm{Cu}, \mathrm{Zn}$ and $\mathrm{Cd}$ ) in the attached materials on the surface of stones on the river bed

\begin{tabular}{c|c|r|r|r|r}
\hline Factor & $\begin{array}{c}\text { Sampling } \\
\text { Site }\end{array}$ & $\mathrm{A}$ & \multicolumn{1}{c|}{$\mathrm{B}$} & $\mathrm{C}$ & $\mathrm{D}$ \\
\hline & 1 & 24800 & 21200 & 32500 & 20600 \\
$\mathrm{Cu}$ & 2 & 10400 & 16900 & 8130 & 24600 \\
$(\mu \mathrm{g} / \mathrm{g})$ & 3 & 1600 & 8820 & 2490 & 82300 \\
& 4 & 1500 & 6540 & 2550 & 76000 \\
\hline & 1 & 8900 & 7260 & 8070 & 5750 \\
$\mathrm{Zn}$ & 2 & 11400 & 10200 & 5580 & 13600 \\
$(\mu \mathrm{g} / \mathrm{g})$ & 3 & 6680 & 7150 & 3540 & 40600 \\
& 4 & 4450 & 5330 & 2100 & 36000 \\
\hline & 1 & 15.0 & 3.8 & 13.0 & 7.4 \\
$\mathrm{Cd}$ & 2 & 24.0 & 12.0 & 9.3 & 11.0 \\
$(\mu \mathrm{g} / \mathrm{g})$ & 3 & 30.0 & 14.0 & 14.0 & 9.5 \\
& 4 & 22.0 & 15.0 & 8.7 & 18.0 \\
\hline
\end{tabular}

Table 4 Concentration of heavy metals $(\mathrm{Cu}, \mathrm{Zn}$ and Cd) in the mud on the river bed

\begin{tabular}{c|c|c|r|r|r}
\hline Factor & $\begin{array}{c}\text { Sampling } \\
\text { Site }\end{array}$ & $\mathrm{A}$ & $\mathrm{B}$ & $\mathrm{C}$ & $\mathrm{D}$ \\
\hline & 1 & 7660 & 12500 & 5970 & 15600 \\
$\mathrm{Cu}$ & 2 & 2890 & 770 & 1400 & 2560 \\
$(\mu \mathrm{g} / \mathrm{g})$ & 3 & 1280 & 500 & 690 & 980 \\
& 4 & 1300 & 670 & 960 & 1200 \\
\hline & 1 & 2510 & 3520 & 1580 & 3000 \\
$\mathrm{Zn}$ & 2 & 1660 & 833 & 960 & 1300 \\
$(\mu \mathrm{g} / \mathrm{g})$ & 3 & 1280 & 890 & 917 & 940 \\
& 4 & 1480 & 800 & 881 & 820 \\
\hline & 1 & 5.0 & 4.1 & 2.7 & 4.2 \\
$\mathrm{Cd}$ & 2 & 5.2 & 1.7 & 2.5 & 2.8 \\
$(\mu \mathrm{g} / \mathrm{g})$ & 3 & 7.3 & 2.8 & 3.7 & 3.3 \\
& 4 & 7.8 & 3.0 & 8.4 & 2.7 \\
\hline
\end{tabular}

of the heavy metals in mud on the river bed were as follows; $\mathrm{Cu}$ was from $500 \mu \mathrm{g} / \mathrm{g}$ (B, Site 3) to $15600 \mu \mathrm{g} / \mathrm{g}$ (D, Site 1); $\mathrm{Zn}$ from 800 $\mu \mathrm{g} / \mathrm{g}(\mathrm{B}$, Site 4) to $3520 \mu \mathrm{g} / \mathrm{g}$ (B, Site 1); Cd from $1.7 \mu \mathrm{g} / \mathrm{g}(\mathrm{B}$, Site 2$)$ to $8.4 \mu \mathrm{g} / \mathrm{g}$ (C, Site 4$)$.

$\mathrm{Cu}$ decreased before flood(A) in Sites 2 and 4. The values of $\mathrm{Cu}$ were only $17 \%$ of there obtained at Site 1 . The same tendency was observed in surveys after flood(B, C, D). But after the flood, the values of Site 4 were a slightly higher than those obtained at Site 3 .

Zn showed high values in every sampling time and decreased from Site 1 to Site 4 in order.

Cd showed higher values in Sites 3 and 4 than those obtained at upstream sites, but 40 days after flood(B) showed opposite tendency. As shown in Tables 3 and 4, regardless of survey time and Survey site, the concentration of $\mathrm{Cu}, \mathrm{Zn}$ and $\mathrm{Cd}$ in attached materials give higher values than those of the concentration of $\mathrm{Cu}, \mathrm{Zn}$ and $\mathrm{Cd}$ in the mud.

\section{Epilithic diatom assemblages on the river bed \\ 1) The structure of diatom assemblages}

Main constituent of attached materials on the river bed is epilithic algal communities. In this research diatom assemblages belonging to a attached algal community, were surveyed four times in all sites; once before the flood and three times after the flood.

$73 \operatorname{taxa}(20$ genera) were identified in this survey. The number of taxa belonging to the genus Navicula was 15 and the number of taxa belonging to Gomphonema was 12 .

Table 5 shows the main diatom taxa and their relative abundance of 4 sites in each sampling time. The name of taxa whose relative abundance does not exceed $1 \%$ at any station of sampling-time were omitted from the table.

It is clear that the strongest affect of the flood was observed at site after flood(B). No diatom assemblage was found at this site.

2) The most abundant taxon and their relative abundance

The taxon with the most relative abundance is the specific composition of diatom assemblages are shown in Fig.2. As shown in Fig.2 11 diatom assemblages out of 
Table 5 Main diatom taxa and their relative abundance(\%) at 4 sites in each sampling time

\begin{tabular}{|c|c|c|c|c|c|c|c|c|c|c|c|c|c|c|c|c|}
\hline \multirow[b]{2}{*}{ Species $\quad$ Sampling Site } & \multicolumn{4}{|c|}{ Sep. 4, 1998(A) } & \multicolumn{4}{|c|}{ Nov. $2,1998(B)$} & \multicolumn{4}{|c|}{ Dec. $21,1998(C)$} & \multicolumn{4}{|c|}{ Mar. 24, 1999(D) } \\
\hline & 1 & 2 & 3 & 4 & 1 & 2 & 3 & 4 & 1 & 2 & 3 & 4 & 1 & 2 & 3 & 4 \\
\hline Achnanthes japonica & & 4.7 & 9.8 & 8.2 & & 3.7 & 1.5 & & 2.3 & 1.0 & 1.0 & & 1.7 & 1.6 & 4.2 & 1.5 \\
\hline A. lanceolate & 4.2 & & 3.3 & 1.9 & & & & 1.1 & & & 1.0 & & & 1.0 & 2.1 & 2.5 \\
\hline A. minutissima & 93.2 & 12.6 & 45.2 & 13.4 & & 92.6 & 73.3 & 11.3 & 84.2 & 79.1 & 28.2 & 76.2 & 95.0 & 85.9 & 52.9 & 48.0 \\
\hline Amphora pediculus & & 3.5 & 3.3 & 1.2 & & & & & 1.3 & & & & & & & \\
\hline Cocconeis plascentula var. lineata & & & & & & & & & & & & & & & & 1.2 \\
\hline Cymbella minuta & & 1.9 & 1.3 & 2.4 & & & & 2.4 & & 1.2 & 2.6 & 1.5 & & & 2.4 & 2.2 \\
\hline C. turgidula var. nipponica & & & & & & & & 1.3 & & & 1.0 & & & & & \\
\hline Diatoma hiemale var. mesodon & & & & & & & & 1.1 & 3.5 & & & & & & & 5.5 \\
\hline Eunotia minor & & & 1.3 & & & & & & & & & & & & & \\
\hline Gomphonema angustatunn & & & & & & & & 2.7 & & & & 1.1 & & & & 1.5 \\
\hline G. clevei & & & 1.3 & & & & & & & & & & & & & \\
\hline G. helveticum & & 1.6 & 3.6 & & & & & & & & & & & & & \\
\hline G. minutum & & & 1.0 & 1.6 & & & & 3.3 & & & 2.6 & 3.3 & & & & \\
\hline G. parvulum & & & 1.3 & 3.8 & & & & 1.1 & & & 1.4 & 1.3 & & & & \\
\hline Melosira varians & & 1.9 & 1.3 & 2.1 & & & & & & 4.2 & 4.8 & & & & 2.7 & 1.8 \\
\hline Navicula pupula & & & 2.6 & & & & & & & & & & & & & \\
\hline$N$. ventralis & & & 3.0 & 4.9 & & & 1.4 & 1.8 & & & 1.8 & & & & 2.1 & 2.2 \\
\hline Nitzscha parvula & & & 1.0 & & & & & & & & & & & & & \\
\hline Surirella angusta & 2.6 & 66.9 & 16.4 & 52.0 & & 1.7 & 12.9 & 54.3 & 4.2 & 7.8 & 13.3 & 9.7 & 2.2 & 4.8 & 4.2 & 4.0 \\
\hline S. biseriata & & & & 1.2 & & & & & & & & & & & & \\
\hline S. ovata var. pinnata & & & & 1.9 & & & 4.9 & 13.7 & & & 32.2 & 2.9 & & 1.0 & 7.7 & 18.5 \\
\hline Synedra rumpens & & & 1.0 & & & & & & & & 1.0 & & & & 4.7 & 2.2 \\
\hline S. ulna & & & & & & & & & & & 2.2 & & & & & \\
\hline S. ulna var. ramesi & & & & & & & & & & & & & & & & 1.2 \\
\hline Total number of taxa occurred & 3 & 19 & 25 & 27 & 0 & 10 & 20 & 22 & 15 & 24 & 33 & 18 & 6 & 22 & 41 & 31 \\
\hline Total number of valves counted & 309 & 317 & 305 & 425 & 0 & 462 & 588 & 451 & 311 & 502 & 503 & 546 & 534 & 505 & 337 & 325 \\
\hline
\end{tabular}

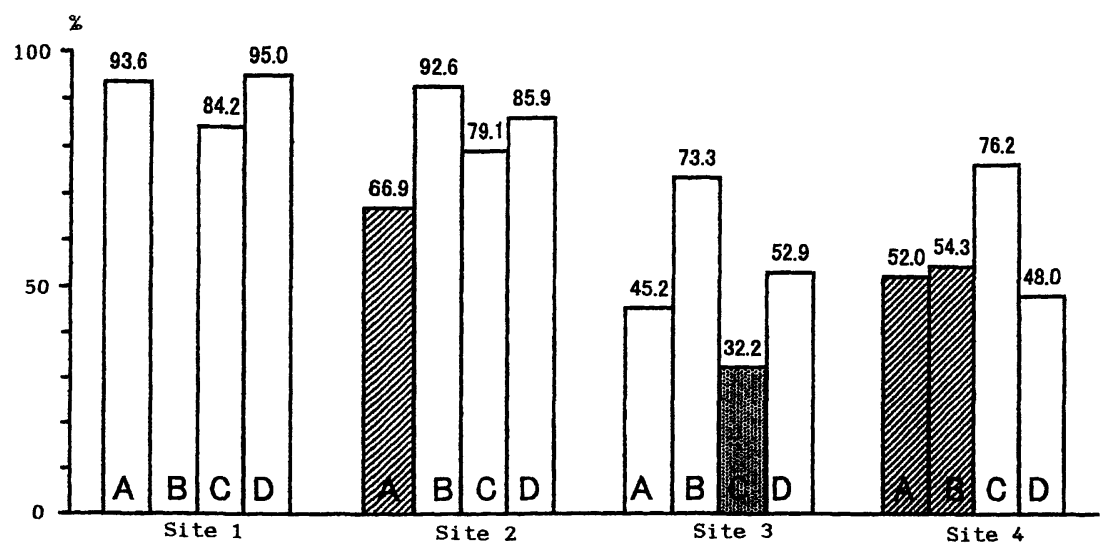

Fig. 2 The most abundant taxon in the diatom assemblages

$\begin{array}{ll}\square \text { : Achnanthes minutissima } & \text { A: Before flood } \\ \text { : Surirella angusta } & \text { B: } 40 \text { days after flood } \\ \text { : S. ovata var. pinnata } & \text { C: } 80 \text { days after flood } \\ & \text { D: } 150 \text { days after flood }\end{array}$


15, Achnanthes minutissina was the most abundant taxon and the range of its relative abundance was from $45.9-95.2 \%$.

In three diatom assemblages(A, Site 2 and 4, B, Site 4) Surirella angusta was the most abundant taxon and the relative abundance was from $1.7-66.9 \%$.

In one diatom assemblage(C, Site 3$), S$. ovata var. pinnata was the most abundant taxon and the relative abundance was $32.2 \%$.

3) The number of taxa and Shannon's diversity index

Shannon's diversity index(Di) was obtained in all epilithic diatom assemblages. As shown in Table 6, the range of $\mathrm{Di}$ was from 0.3 to 1.3.

The fact that both in the upstream area(sites 1,2) and in the downstream area (sites 3, 4) the Di showed comparaively small values indicates that the main cause of the river water pollution was the heavy metals $(\mathrm{Cu}, \mathrm{Zn}$ and $\mathrm{Cd})$.

\section{SYNTHETIC CONSIDERATION}

\section{EC in river water}

Each survey showed a tendency in its measurement of EC values, which reduced from Site 1 to Site 4 in order. The concentration of heavy metal ions in the river water was naturally diluted. There is no inflow of rivers containing heavy metal ions. This situation remained the same after the flood.

\section{Concentration of heavy metals $(\mathrm{Cu}, \mathrm{Zn}$ and $\mathrm{Cd}$ ) in the river water}

As shown in Table 2, the values of heavy metals increased in each site after the flood, and this tendency continued about 6 months. Concentration of ions heavy metals in the river water was highest near, Site 1 . But it was no diluted naturally on middle and lowstream.

Also in this case, as in the case of EC values each survey showed a tendency in the measurement of concentration which reduced from upstream to downstream.

At each site, 6 months after the flood, the values of $\mathrm{Cu}, \mathrm{Zn}$ and $\mathrm{Cd}$ were greater than those obtained before the flood(Table 2).

This fact may be considered as the result of the process in which the attached materials on the river bed easily came off and were carried downstream, and piled up there. But more detailed survey must be undertaken before a definite conclusion can be reached.

3. The concentration of heavy metals in the attached materials and mud on river bed

It is obvious from Tables 3 and 4, that the concentration of heavy metals in attached materials was far higher than in river mud.

This may be due to the fact that the great part of attached material consisted of epilithic algae(organic material). After all the weight of epilithic algae per unit volume is small compared with silt, but they absorb and concentrate heavy metals. On the other hand, inorganic silt only absorbs heavy metals but no process of concentration occurs. So as shown in Tables 3 and 4, the concentration of heavy metals in attached materials is much higher than in silt.

\section{The most abundant taxon in epilithic diatom assemblages}

28 years have passed since the Ogoya mine was closed, but the specific structure of epilithic diatom assemblage sample taken at each sampling site was still affected by heavy metals.

In these water areas, Achnanthes minutissima which has strong tolerance,

Table 6 Number of taxa and Shannnon's diversity index(Di) of diatom assenblage

\begin{tabular}{c|c|c|c|c|c|c|c|c}
\hline & \multicolumn{2}{|c|}{ A } & \multicolumn{2}{c|}{ B } & \multicolumn{2}{c}{ C } & \multicolumn{2}{c}{ D } \\
\hline $\begin{array}{c}\text { Sampling } \\
\text { Site }\end{array}$ & $\begin{array}{c}\text { Total } \\
\text { number } \\
\text { of taxa }\end{array}$ & $\begin{array}{c}\text { Shannon's } \\
\text { diversity } \\
\text { index(bit) }\end{array}$ & $\begin{array}{c}\text { Total } \\
\text { number } \\
\text { of taxa }\end{array}$ & $\begin{array}{c}\text { Shannon's } \\
\text { diversity } \\
\text { index(bit) }\end{array}$ & $\begin{array}{c}\text { Total } \\
\text { number } \\
\text { of taxa }\end{array}$ & $\begin{array}{c}\text { Shannon's } \\
\text { diversity } \\
\text { index(bit) }\end{array}$ & $\begin{array}{c}\text { Total } \\
\text { number } \\
\text { of taxa }\end{array}$ & $\begin{array}{c}\text { Shannon's } \\
\text { diversity } \\
\text { index(bit) }\end{array}$ \\
\hline 1 & 3 & 0.29 & & & 15 & 0.76 & 6 & 0.26 \\
2 & 19 & 1.31 & 10 & 0.35 & 24 & 0.95 & 22 & 0.76 \\
3 & 25 & 2.03 & 20 & 1.08 & 33 & 2.85 & 41 & 2.13 \\
4 & 27 & 1.83 & 22 & 1.70 & 18 & 2.13 & 31 & 1.88 \\
\hline
\end{tabular}


occupies its position as the most abundant taxon, among taxon, diatom assemblage.

In almost all sites at the period $\mathrm{B}(40$ days after flood), the abundant taxon was $A$. minutissima except at Site 4.

It is worth noting that in all sites at the period $\mathrm{D}$ (150 days after flood), the most abundant taxon was $A$. minutissima.

The changes of the abundant taxon in Sites 3 and 4, signifying the increase of pollution materials, were considered to be due to the fact that materials on the river bed easily came off and were carried downstream and piled up there temporarily.

The changes, however, might also be considered to be due to a crop-out of a copper vein caused by the flood.

In this case the effects of heavy metals in the river water are expected to extend over a considerable length of time. In order to investigate and clarify this sitution, we intend to focus our attention on the changes of epilithic diatom assemblages for sometime in the future in the same area.

\section{REFFERENCE}

1) Gose, K.: On the influence of mineeffluent of the Kamioka Mine (Gifu Prefecture), Ogoya Mine (Ishikawa Prefecture) and Hosokura Mine (Miyagi Prefecture) on stream organisms, Jap. J. of Ecology, Vol.11, 111-117(1961) (in Japanese)

2 ) Sunita M., and Watanabe T.: Limnologial studies on the mine pollution of the Godani-gawa River and the Kakehashigawa River., Ann. Rep. Noto Mar. lab., Vol.13, 85-94(1973) (in Japanese)

3 ) Watanabe T. and Sumita M.: Accumulation of some heavy metals by epilithic organisms and silt on the river bed in the Kakehashi-gawa River and its algal flora., Jap. J. Water Treat. Biol., Vol.12, No.1, 65-72(1976) (in Japanese)

4 ) Hatakeyama M., Fukushima S., and Satake K.: On the recovery process of flora and fauna in the heavy metal pollution river, the Kakehashi River in the Hokuriku District., Res. Rep. Natl., Inst. Environ. Stud., No.114, 193-206(1988) (in Japanese)
5 ) Sunita M: The changed of attached diatom assemblages, twenty-three years after the closing of Ogoya mine, on the river bed of the Kakehasi and its tributary, the Godani, in Komatsu City, Jour. Biol. Edu. Ishikawa Pref., No.32, 35 -42(1996) (in Japanese)

6 ) Ito, T.: Indicator organisms for the inorganic pollution, In: Environments and indicator organisms (ed. Special committed for the environmental problem in the ecological society of Japan), 13 -39, Kyoritsu Publisher, Tokyo (1975) (in Japanese)

7 ) Honjo T. and Annen M.: Studies of analysis and dissolving form of trraceamount of heavy metals of spa in Ishikawa prefecture, J. Sol. Eug. Mineral Springa, Mineral Springs, Vol. 15, No.1, 1 -6(1980) (in Japanese)

8 ) Oda T. and Honjo T.: Characterization of Copper, lead and Zinc in metal tolerant mosses, Atrichum undulatum(Hedw.) $P$. Beauv., Scopelophila cataracta(Mitt.) Broth Pohlia bulbifera(Warnst.)Warnst. In heavy metals pollution areas, J. Phytogeogr. and taxon, Vol.43, 91-102 (1995)

9 ) Watanabe T.. et al.: Studies of the quantitative water quality estimation of freshwater pollution using diatom communities as the biological indicater (1), Ann. Rep. Nissan Sci. Found., Vol.10, 336-341(1983)(in Japanese)

10) Cleve-Euler: Diatomen von Schweden und Finland I-V, K. SV. Hand., 2(1): 1-163, 4(1):1-158, 4(5):1-225, 5(4):1-232 (19511955)

11) Hustedt, F.: Bacillariophyta(Diatomeae), 1 -446, In a Pascher(ed.)., Die Süsswasser Flora Mitteleuropas, 10, Gustav Fisher Verlag, Jena(1930)

12) Hustedt, F.: Die Kieselalgen Deutschland, Osterreichs und der Schweiz Beruksichtigund der ubriben Lander Europas so wie der angrenzeden Meers gibiete, In: Rabenhorst(ed.) KryptgamenFlora, I, II and III, Leipzing(1933, 1977)

13) Krammer $K$. und $H$. Lange-Bertalot: Bacillariophyceae. Teil 1, 1-876, Teil 2, 1 -539, Teil 3, 1-576, Teil 4, 1-437, In: H. Ettl. J. Gerloff, H. Heynig, D. 
Mollenhauer(eds.), Süsswasserflora von Mitteleuropa, Gustav Fischer Verlag, Stuttgart, New York(1986, 1988, 1991a, 1991b)

14) Patrick R. and Reimer, C. W.: The diatoms of the United States 1:1-788, 2(1): 1-213, Acad. Sci., Philadelphia, Philadelphia
(1966-1975)

15) Simonsen R.: Atlas and catalogue of the diatom types of Fredrich Hustedt.1:1525, II:plate 1-395, III:plate 396-772, J. Cremer, Berlin, Stuttgart(1987)

(Submitted 2003. 3. 7)

(Accepted 2003. 10. 31) 